Received: May, 2019

Accepted: November, 2019

ISSN $2006-6996$

\title{
ANTIULCEROGENIC ACTIVITY OF METHANOL EXTRACT FROM Ipomoea asarifolia LEAVES IN WISTAR RATS
}

\author{
${ }^{* 1}$ Aiwonegbe, A. E., ${ }^{2}$ Omenai, I. F., ${ }^{1}$ Ogbeide, K. O., ${ }^{3}$ Benjamin, G. O. and ${ }^{1}$ Eikpe,
} I. $\mathbf{R}$.

${ }^{1}$ Department of Chemistry, University of Benin, Benin City, Nigeria.

${ }^{2}$ Department of Chemistry, College of Education Ekiadolor-Benin, Edo State Nigeria.

${ }^{3}$ Department of Pharmacology, University of Benin, Benin City, Nigeria

*correspondence author: anthony.aiwonegbe@uniben.edu; Tel: +2348033116109

\begin{abstract}
The phytochemical constituents and the antiulcerogenic activity of methanolic extract from Ipomoea asarifolia leaf were investigated to ascertain its medicinal potentials. The study revealed that the leaf contained saponins, tannins, alkaloids, terpenoids and eugenols. The methanolic extract was used as a protective agent against gastric ulcer in Wistar rats, using the experimental model of gastric ulcer (lesion) induced by ethanol. The ulcer count for the methanol extract ranged from 0.00 to 2.00, while the ulcer index ranged between 0.33 to 2.00 for all concentrations (100, 200 and $400 \mathrm{mg} / \mathrm{kg})$. Percentage inhibition at 100, 200 and $400 \mathrm{mg} / \mathrm{kg}$ were respectively $25.09 \%, 12.73 \%$ and $87.64 \%$. The extract prevented acute gastric mucosal injury induced by absolute ethanol in a non dose-dependent manner. This is because the protective action was observed at the lowest and highest doses, but not an intermediate dose of the extract. The results obtained indicate that the leaf extract has antiulcerogenic importance and may be utilized for the treatment of gastric ulcers.
\end{abstract}

Key words: Antiulcerogenic, extract, phytochemical, Ipomoea asarifolia, stomach

\section{INTRODUCTION}

The use of plants as medicine has become the mainstay of traditional health care system amongst rural communities worldwide (Sarker and Nahar, 2007). The therapeutic use of plants certainly dates back to the beginning of civilisation, as old as mankind. Over the years, these plants have assumed a central stage in modern civilisation as a natural source of medicine as well as in scientific studies amongst scientists in search for alternative sources of drugs. About $80 \%$ of plants selected for analysis on the basis of ethno-medicinal information have demonstrated significant pharmacological activity (Fatope, 2001).

According to the World Health Organisation (WHO, 2013), a medicinal plant is any plant which, in one or more of its organs, contains substances that can be used for therapeutic purposes, or which are precursors for chemopharmaceutical semi-synthesis. Such a plant will have its parts including leaves, roots, rhizomes, stems barks, flowers, fruits, grains or seeds, employed in the control or treatment of a disease condition which maybe associated with chemically active constituents. These nonnutrient plant compounds or bioactive components are often referred to as phytochemicals or phytoconstituents and are responsible for protecting the plant against microbial infections or infestations by pest (Nweze et al., 2004; Doughari et al., 2009). The science and application of these indigenous or local medicinal remedies including plants for treatment of diseases is called ethnopharmacology but the practice dates back as far as the early years of mankind (Doughari and Obidah, 2008).

These plants are applied in various forms such as poultices, concoctions of different plant mixtures, infusions as teas or as component mixtures in porridges and soups, administered in different ways including oral, nasal (smoking, snuffing or steaming), topical (lotions, oils or creams), bathing or rectal (enemas). Different plant parts and components (roots, leaves, stem barks, flowers, essential oils or their combinations) have been employed in the treatment of infectious pathologies in the respiratory system, urinary tract and gastrointestinal systems, as well as on the skin ( $\mathrm{R}^{\prime}$ IOS and Recio, 2005; Adekunle and Adekunle, 2009).

Ipomoea asarifolia (Convolvulaceae) is a glabrous succulent perennial plant trailing on the ground. It reproduces from the seeds and shoots of the stem. It is a creeping or trailing plant that grows on sandy soils or waste lands. 
BAJOPAS Volume 12 Number 2, December, 2019

It is found throughout West Africa from Nigeria to Senegal, Mali, the Cape Verde Island, and tropical Asia (Jegede et. al., 2009). It is used for the treatment of disease conditions such as ulcers by various rural dwellers and traditional medicinal practitioners in Africa. In some parts of Africa, like Senegal, it is used traditionally for various gynaecological purposes such as haemorrhage; urinary problems during pregnancy; as an abortifacient and for the treatment of headache, arthritic pains and stomach ache. In Ivory Coast, a leaf decoction is usually taken internally as a wash for feverish chills and rheumatic pains. In northern Nigerian, the leaf poultice (a moist substance spread on cloth and placed on the skin) is applied to guinea worm sores while the face is steamed over a hot decoction of the plant along with husks of bulrush millet. The flowers are also boiled with beans and eaten as a remedy for syphilis The leaves are also used to treat dysmenorrhoea (painful menstruation) in the middle belt of Nigeria (Atawodi and Onaolapo, 2010).

A sub-chronic (90-day) toxicity trial in rats has also shown that an aqueous-ethanolic extract of Ipomoea asarifolia plant, when administered intraperitoneally, is relatively safe up to a dose of $1000 \mathrm{mg} / \mathrm{kg}$ (Akindele et al., 2015).

This study was therefore conducted to provide a scientific basis for the use of Ipomoea asarifolia leaves in the treatment and/or management of gastric ulcers by reviewing and analyzing the protective and therapeutic agents present and provide evidence for its effectiveness and potency in modern investigations for treatment of ulcers. There are a number of models that are available to test substances for their antiulcerogenic effects. Here, we report on the effect of methanolic extract of Ipomoea asarifolia leaves on gastric lesion (ulcer) induced in Wistar rats by employing absolute ethanol.

\section{MATERIALS AND METHODS Plant material}

Leaves of Ipomoea asarifolia were collected in Ekosodin community, Benin City, Edo State, Nigeria at the location $6^{0} 24^{\prime} 26.8^{\prime \prime} \mathrm{N} 5^{0} 36^{\prime} 41.8^{\prime \prime} \mathrm{E}$. The plant was identified and authenticated at the Department of Plant Biology and Biotechnology, University of Benin, Nigeria by Prof. Emmanuel Isaka Aigbokhan.

The leaves were washed and dried under shade for two weeks (14 days) in the labouratory at the University of Benin, Chemistry Annex building. The dried leaves were pulverized to fine powder by using an electric grinder.

\section{Extract preparation}

Extraction of the plant material was done according to the method described by Aliyu et al., (2011), with some modifications. $85 \mathrm{~g}$ of the powdered plant material was soaked in 1 litre $(1000 \mathrm{ml})$ of $70 \%$ methanol, in a stoppered container. The mixture was then intermittently agitated every 20minutes for I hour and left for twenty-four (24) hours to allow soluble matter dissolve. Thereafter, the mixture was filtered using No.1 Whatman filter paper $(18 \mathrm{~cm}$ in diameter) and the resulting extract was concentrated using a water bath, set at $60^{\circ} \mathrm{C}$ to obtain the crude extract. The extract was collected in a sample bottle and kept in a refrigerator for phytochemical analysis and bioassay.

\section{Phytochemical screening}

The phytochemicals present in $I$. asarifolia leaves were qualitatively analyzed using the methods described by Soforowa (1993) as well as Trease and Evans (2002).

\section{Animals}

After obtaining clearance from the Ethics Committee on the use of animals for studies, fifteen (15) male Wistar rats, weighing between $137 \mathrm{~g}$ and $194 \mathrm{~g}$, were obtained from the Faculty of Pharmacy, and kept in the Animal House, Department of Pharmacology and Toxicity, University of Benin. The rats were kept in metalwalled cages in groups of three (3). They were fed daily with formulated dual mash feed and allowed free access to water. The rats were maintained under normal environmental conditions for one week (7 days) in order for them to acclimatize.

\section{Treatments}

Doses of 100,200 and $400 \mathrm{mg} / \mathrm{kg}$ of Ipomoea asarifolia extract were prepared as aqueous suspensions. Cimetidine $(100 \mathrm{mg} / \mathrm{kg})$ and $10 \mathrm{ml} / \mathrm{kg}$ deionised water were used as the reference drug and control vehicle respectively. All treatments were administered orally (gavage), 30 minutes before the procedures for inducing gastric ulcer.

\section{Ethanol-induced gastric ulcer}

The rats were divided into five groups of three each. The rats were starved of food but allowed access to water 24 hours before the study. Rats in Group I were pre-treated with water $(10 \mathrm{ml} / \mathrm{kg})$, to serve as the control. Rats in Group II were administered Cimetidine, standard drug, at a dose of $100 \mathrm{mg} / \mathrm{kg}$. Rats in Groups III, IV and $V$ received the extract at doses of 100, 200 and $400 \mathrm{mg} / \mathrm{kg}$ respectively. $1 \mathrm{ml}$ of absolute ethanol (99\%) was then administered to all the animals 30 minutes after the pre-treatment. 
BAJOPAS Volume 12 Number 2, December, 2019

Each group was placed in a transparent observation box. Sixty (60) minutes after the ethanol administration, the rats were sacrificed. The stomachs were then removed, examined, the number of lesions counted and the degree of severity recorded (Shirisha and Subash, 2012). The ulcer count and ulcer index were calculated in relation to the control group. The activity was also expressed as percentage ulcer inhibition. The stomach tissue from each group was then taken, placed in a sample bottle filled with formalin (as a preservative) for further histological studies.

Scoring of the ulcer was done as follows: Normal stomach $=0.00$; Red coloration $=0.50$; Spot ulcer = 1.00; Hemorrhagic streak = 1.50; Ulcers $=2.00$ and Perforation $=3.00$.

Mean ulcer score for each animal is expressed as ulcer index.

The percentage of ulcer protection was determined using the formular:

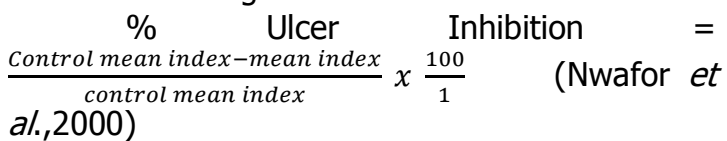

\section{HISTOPATHOLOGY}

The stomach tissue samples harvested from the rats were fixed in buffered formalin for 24 hours. Sections of tissue from stomachs were examined histopathologically to study the ulcerogenic and/ or anti-ulcerogenic activity of Ipomoea asarifolia leave extract. The tissues were fixed in $10 \%$ buffered formalin and were processed using a tissue processor. The processed tissues were embedded in paraffin blocks and about $5-\mu \mathrm{m}$ thick sections were cut using a rotary microtome. These sections were stained with hematoxylin and eosin using routine procedures. The slides were examined microscopically for patho-morphological changes such as congestion, haemorrhage, oedema and erosions using an arbitrary scale for the assessment of severity of these changes (Slaoui and Fiette, 2011).

\section{RESULTS AND DISCUSSION}

The results for the phytochemical screening of Ipomoea asarifolia leaf extract are presented in Table 1 below. The extract was found to contain saponins, tannins, alkaloids, terpenoids and eugenols. However, carbohydrates, glycosides, steroids, reducing sugars and flavonoids were not detected. The results compare favourably with those obtained for the leaves of $I$. asarifolia by Jegede et al., (2009) and Aliyu et al., (2011) who reported the presence of alkaloids, tannins and saponins in the plant leaves

Table 1. Results of phytochemical screening of Ipomoea asarifolia leaf extract.

\begin{tabular}{lc}
\hline Phytochemicals & Results \\
\hline Carbohydrate & -- \\
Phenolic compounds & -- \\
Saponins & ++ \\
Terpenoids & ++ \\
Alkaloid & ++ \\
Tannins & ++ \\
Steroids & -- \\
Reducing sugar & -- \\
Flavonoids & -- \\
Eugenols & ++ \\
Glycosides & -- \\
\hline
\end{tabular}

Key: $++=$ present $--=$ absent

The presence of these secondary plant metabolites shows a great potential for the application of $I$. asarifolia as a useful source of plant medicine. Several studies have shown the potentials of these phytochemicals in ulcer gastric treatment. This is supported by the report that tannins act by inhibiting the secretion of gastric acids (Jhansirani et al., 2010), while alkaloids protect the gastric mucosa from damage caused by absolute ethanol through the scavenging of free radicals (Konturek et al., 1997). Also, saponins have been shown to have significant effect in lowering ulcer index, while significantly increasing percentage protection against ethanol and restrained stress induced ulcer model in rats. Saponins aid increased levels of defensive mucin secretion in terms of total carbohydrate to protein ratio, thus being active in alleviating ulcers (Mohammad et al., 2012). 
BAJOPAS Volume 12 Number 2, December, 2019

Table 2. Effect of methanolic extract of Ipomoea asarifolia on ethanol-induced gastric ulcer in wistar rats.

\begin{tabular}{lcc}
\hline Treatment & Mean ulcer index & Percentage inhibition (\%) \\
\hline Water $(10 \mathrm{ml} / \mathrm{kg})$ & 2.67 & - \\
I. asarifolia & & \\
$100 \mathrm{mg} / \mathrm{kg}$ & 2.00 & 25.09 \\
$200 \mathrm{mg} / \mathrm{kg}$ & 2.33 & 12.73 \\
$400 \mathrm{mg} / \mathrm{kg}$ & 0.33 & 87.64 \\
Cimetidine $(100 \mathrm{mg} / \mathrm{kg})$ & 1.33 & 50.18 \\
\hline
\end{tabular}

The results of the effect of methanol extract of I. asarifolia on ethanol-induced gastric ulcers in Wistar rats are shown in Table 2 and also displayed pictorially on Plates $1,2,3,4$ and 5 . Ethanol-induced gastric lesion formation may be due to stasis in gastric blood flow which contributes to the development of the haemorrhage and necrotic aspects of tissue injury. This is very evident in Plate 1 for animals treated with deionised water at $10 \mathrm{ml} / \mathrm{kg}$.

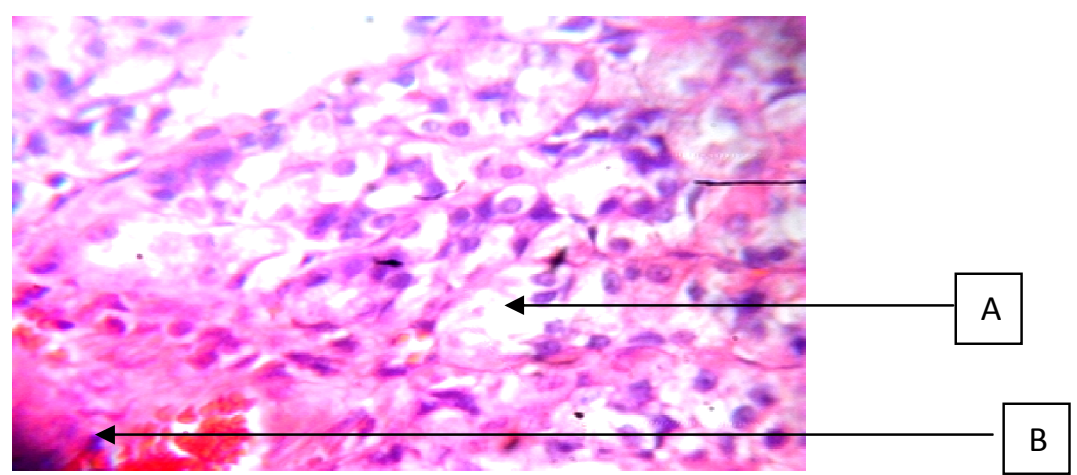

Plate 1: Stomach lining showing [A]: mild stomach lesion with [B]: severe haemorrhage. Treatment: Deionised water $(10 \mathrm{ml} / \mathbf{k g})$.

Alcohol rapidly penetrates the gastric mucosa apparently causing cell and plasma membrane damage leading to increased intra-cellular membrane permeability to sodium and water. The resultant massive intracellular accumulation of calcium represents a major step in the pathogenesis of gastric mucosal injury. This leads to cell death and exfoliation on the surface (Raju et al., 2009).
The extract showed protection against characteristic lesions produced by ethanol administration. The protective action against lesions was offered by the plant extract at varying degrees depending on the dosage.

Plate 2 shows the highest percentage inhibition $(87.64 \%)$ which was observed at a dose of 400 $\mathrm{mg} / \mathrm{kg}$ of the extract. There was no observable haemorrhage and the stomach lining is seen to be covered with mucosa lining.

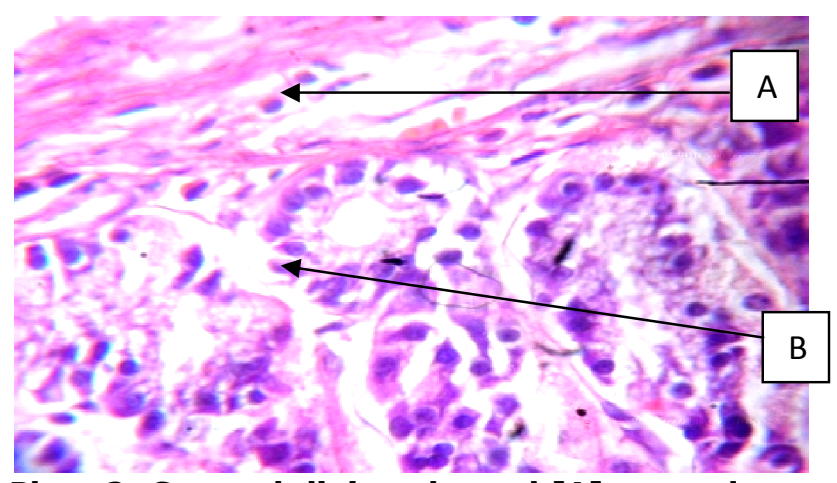

Plate 2: Stomach lining showed [A]: coated stomach with mucosa lining [B]: little or no lesion with absence of haemorrhage.

Treatment: I. asarifolia extract $(400 \mathrm{mg} / \mathrm{kg})$. 
BAJOPAS Volume 12 Number 2, December, 2019

This antiulcer effect of the plant extract may have reduced gastric acid secretion leading to gastric cytoprotection. This is highly comparable to the effect produced by the standard drug,
Cimetidine, which gave a percentage inhibition of $50.18 \%$ when administered at a dose of 100 $\mathrm{mg} / \mathrm{kg}$ as shown in Plate 3 below.

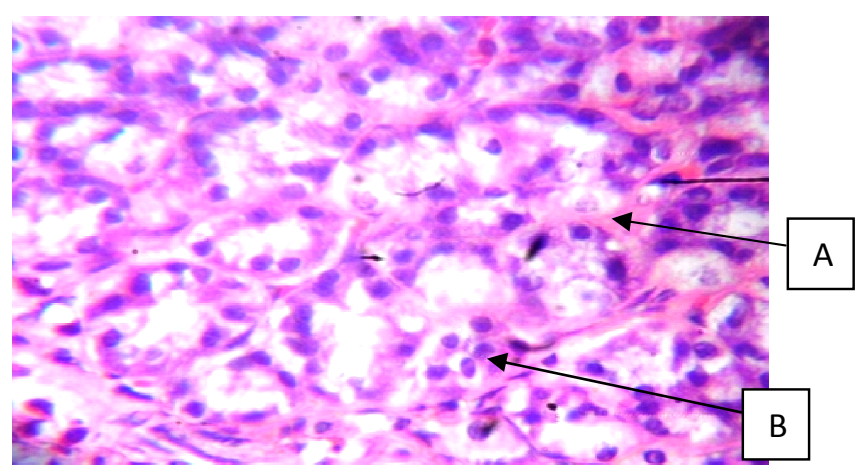

Plate 3: Stomach lining showing [A]: mucosa membrane with a well-defined and healthy stomach

[B]: thick coating of the stomach lining.

Treatment: Cimetidine (100mg/kg).

Since the result of the phytochemical screening of $I$. asarifolia leaf extract shows that it contains saponins, tannins, alkaloids, terpenoids and eugenols, it allows us to suggest that the antiulcerogenic effect of $I$. asarifolia leaf extract may be associated with the presence of these phytochemicals in the plant (Jhansirani et al., 2010).
However, the intermediate dose of $200 \mathrm{mg} / \mathrm{kg}$ of the extract of $I$. asarifolia leaf gave the least percentage inhibition $(12.73 \%)$ whereas the lowest dose administered $(100 \mathrm{mg} / \mathrm{kg}$ ) gave a better protection of $25.09 \%$. These effects are respectively shown in Plates 4 and 5 below.

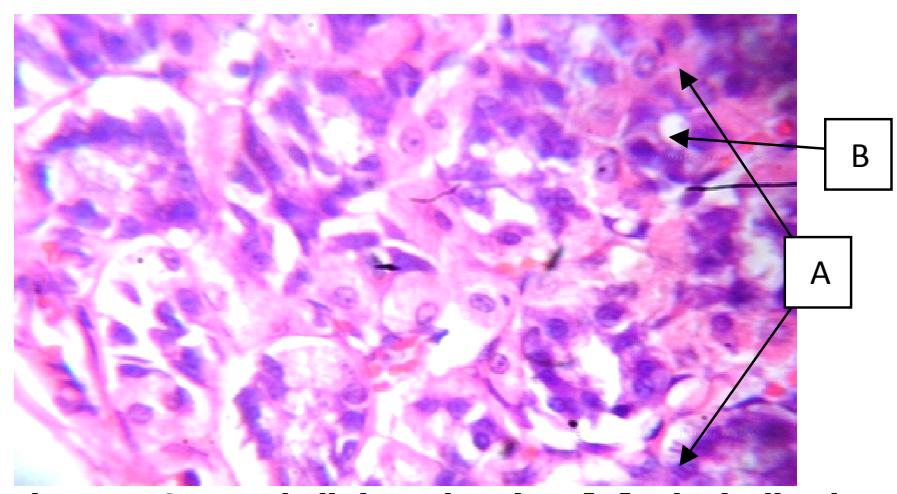

Plate 4: Stomach lining showing [A]: devitalised stomach and [B] lesion with spotted haemorrhage indicating ulceration.

Treatment: I. asarifolia extract $(200 \mathrm{mg} / \mathrm{kg})$.

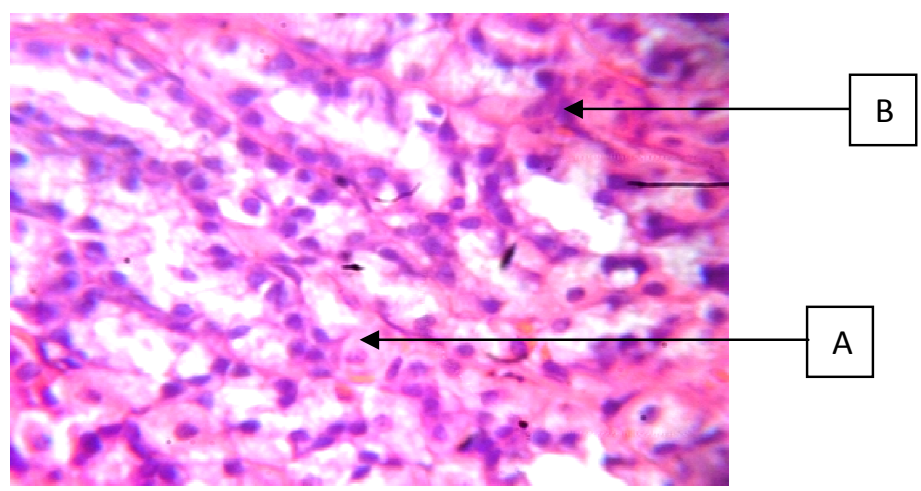

Plate 5: Stomach lining showing [A]: mucosa lining of the stomach and [B] lesion with mild haemorrhage indicating ulceration.

Treatment: $I$. asarifolia extract $(100 \mathrm{mg} / \mathrm{kg})$. 
BAJOPAS Volume 12 Number 2, December, 2019

In this experimental model using ethanol to induce gastric ulcer, the protective action of Ipomoea asarifolia leaf extract was produced at the lowest and at the highest dose, but not at intermediate doses of the extract. This shows that its antiulcer activity is not dose dependent. The specific mechanism underlying this action is however unknown.

\section{CONCLUSION}

The qualitative evaluation of Ipomoea asarifolia leaf extract has shown that it contains various secondary plant metabolites such as saponins, tannins, alkaloids, terpenoids and eugenols, hence making the plant a viable source of plant medicine.

\section{REFERENCES}

Adekunle, A.S. and Adekunle, O.C. (2009). Preliminary assessment of antimicrobial properties of aqueous extract of plants against infectious diseases. Biology and Medicine. 1(3):20-24.

Akindele, A.J., Unachukwu, E.G. and Osiagwu, D.D. (2015). 90-Daystoxicological as sessment of hydroethanolic leaf extract of Ipomoea asarifolia (Desr.) Roem.and Schult. (Convolvulaceae) in rats.Journal of Ethnopharmacology.174:582-594.

Aliyu, M.S., Lawal, U., Tijjani, M.B., Doko, M.H.I., Garba, I., Kokya, H.A., Ado, S.A., Hanwa, U.A. and Ibrahim M.M. (2011). Phytochemical and antibacterial properties of leaf extracts of Ipomoea asarifolia. Nigerian Journal of Basic and Applied Science. 19 (2): 236-240.

Atawodi,S.E.O.and Onaolapo, G.S. (2010). Comparative in vitro antioxidant potential of different parts of Ipomoea asarifolia, Roemer \& Schultes, Guiera senegalensis, J.F.Gmeland Anisopus mannii N. E.Brown. Brazillian Journal of Pharmaceutical Sciences. 46:245-250.

Doughari, J.H., Human, I.S., Bennade, S. and Ndakidemi, P.A. (2009). Phytochemicals as chemotherapeutic agents and antioxidants: Possible solution to the control of antibiotic resistant verocytotoxin producing bacteria. Journal of Medicinal Plants Research. 3(11):839-848.

Doughari, J.H. and Obidah, J.S. (2008). Antibacterial potentials of stem bark extracts of Leptadenia lancifoli against some pathogenic bacteria. Pharmacology online. 3:172-180.

Fatope, M.O. (2001). Natural Products: Looking Backward and Looking Forward. Bayero
This study has also shown that the extract of $I$. asarifolia has significant antiulcerogenic activity on Wistar rats. Therefore, the plant could be exploited for use in the formulation of relatively cheap and effective drug for the treatment of gastric ulcers. However, the mechanisms underlying the protective action of the extract against ethanol-induced gastric lesions are unclear. Further studies using more specific methods are required to explore the compounds responsible for the protective effect, and the mechanism of this activity.

Conclusively, this study supports the traditional use of $I$. asarifolia leaves in the treatment of gastric ulcers.

University, Kano. Inaugurallecture Series No. 4.

Jegede, I.A., Nwinyi, F.C., Ibrahim, J., Ughabe, G., Zarma, S.D. and Kunle, O.F. (2009). Investigation of phytochemical, antiinflammatory and anti-nociceptive properties of Ipomoea asarifolia leaves. Journal of Medicinal Plant Research; 3(3):160-164.

Jhansirani, M., Mohanalaxmi, S. and Sarvanakumar, A. (2010). Evaluation of anti-ulcer activity of methanol extract of Dioscorea oppositifolia tubers in adult wistar rats. International Journal of Preclinical and Pharmaceutical Research. 1(1):19-24.

Konturek, P.C., Konturek, S.J., Majka, J., Zembala, M., and Hahn, E.G. (1997). Melatonin affords protection against gastric lesions induced by ischemiareperfusion possibly due to its antioxidant and mucosal microcirculatory effects. European Journal of Pharmacology. 322:73-77.

Mohammad, A., Nagarajaiah, B.H. and Kudagi, B.L. (2012). Experimental Evaluation of Antiulcer Activity of Cyperus Rotundus. Asian Journal of Biochemical and Pharmaceutical Research. 2(2):261-268.

Nwafor, P.A., Okwuasaba, F.K. and Binda, L. G. (2000). Antidiarrhoeal and antiulcerogenic effects of methanolic extracts of Asparagus pubescens root in rats. Journal of Ethnopharmacology. 72:421 - 427.

Nweze, E.L., Okafor, J.L. and Njoku O. (2004). Antimicrobial Activityies of Methanolic extracts of Trume guineesis (Scchumn and Thorn) and Morinda lucinda used in Nigerian Herbal Medicinal practice. Journal of Biological Research and Biotechnology. 2(1):34-46. 
BAJOPAS Volume 12 Number 2, December, 2019

Raju, D., Ilango, K., Chitra, V., and Ashish, K. (2009). Evaluation of Anti-ulcer activity of methanolic extract of Terminalia chebula fruits in experimental rats. Journal of Pharmacological Science and Research. 1(3): 101-107.

Rìos, J.L. and Recio, M.C. (2005). Medicinal plants and antimicrobial activity. Journal of Ethnopharmacology. 10: 80-84.

Sarker, S.D. and Nahar, L. (2007). Chemistry for Pharmacy Students General, Organic and Natural Product Chemistry. England: John Wiley and Sons.. pp 283-359.

Shirisha B. and Subash, V. (2012). Animal Models In Experimental Gastric Ulcer Screening-A Review. International Journal of Pharmacological Screening methods. 2(2):82-87.
Slaoui, M. and Fiette, L. (2011). Histopathology Procedures: From Tissue Sampling to Histopathological Evaluation In: Methods in molecular biology (Clifton, N.J.) 691:69-82. PubMed. DOI: $10.1007 / 978-$ 1-60761-849-2 4 .

Sofowora, A. E. (1993). Medicinal plants and traditional medicine in Africa. Spectrum Books Ltd. Lagos, Nigeria 2nd edn. pp. 26-61.

Tease, G.E. and Evans, W.C. (2002). A Textbook of Pharmacognosy, 15th Edn. London. Saunders Publishers. pp. 42-93.

World Health Organization (Ed.), (2013). WHO Traditional Medicine Strategy 20142023, WHO Press, Geneva, Switzerland. 